\title{
Collective ritual as a way of transcending ethno-religious divide: the case of Kataragama Pāda Yātrā in Sri Lanka\#
}

\author{
Anton Piyarathne* \\ Department of Social Studies, Faculty of Humanities and Social Sciences, The Open University of Sri Lanka, Nawala, Sri Lanka.
}

\begin{abstract}
Sri Lanka has been in the prime focus of national and international discussions due to the internal war between the Liberation Tigers of Tamil Eelam (LTTE) and the Sri Lankan government forces. The war has been an outcome of the competing ethno-religious-nationalisms that raised their heads; specially in post-colonial Sri Lanka. Though today's Sinhala and Tamil ethno-religious-nationalisms appear as eternal and genealogical divisions, they are more of constructions; colonial inventions and post-colonial politics. However, in this context it is hard to imagine that conflicting ethno-religious groups in Sri Lanka actually unite in everyday interactions. This article, explains why and how this happens in a context wherein essentialisations of ethnic and religious labels prevail, and relations between groups are still tense following years of conflict. Recent fieldwork in the rural village of Pānama revealed that people belonging to two different ethno-religious groups, i.e., Sinhala-Buddhists and Tamil-Hindus, tend to overcome their differences in the context of rituals that blend Hindu and popular Buddhist traditions. Building upon Turner's notion of communitas (1969), as recently applied to the lived religion of pilgrimages (Hermkens et al., 2009), and the theory of practice of Bourdieu (McCorriston, 2011), the annual pilgrimage create space for multi-ethnic devotees to collaborate, which will be useful in creating a psychological frame for long term relationship building.
\end{abstract}

Keywords: Pilgrimage on foot, ethno-religious nationalism, ethno-religious conflict, ethno-religious integration, religious syncretism, Sri Lanka.

\section{INTRODUCTION}

The island of Sri Lanka is home to a multi-ethnic society of approximately 20 million people. The population mainly comprises Sinhalas (74.9\%), Sri Lankan Tamils (11.2\%), Indian Tamils (4.2\%), Sri Lanka Moors, often identified as Muslims (9.2\%), Burghers (0.2\%), Malays ( $0.2 \%)$ and other, ethnic groups that have essentially been linked with particular religions and language groups. Ethnic Sinhalas who are Sinhala speakers, are predominantly Buddhist, whereas the ethnic Tamils, who communicate in the Tamil language, are primarily Hindu. These two ethnic groups are often recognised as rivals involved in an "ethnic conflict" that culminated in war between the LTTE (the Liberation Tigers of Tamil Eelam, a military movement that has battled for the liberation of Sri Lankan Tamils) and the government. Sri Lanka suffered heavily as a result of a three-decade old internal war, which officially ended with the elimination of the leadership of the LTTE in May, 2009. Scholarly literature on the region suggests that "ethno-religious nationalisms" in Sri Lanka in fact polarise the country's ethnic groups, making public life difficult for all or at least for members of certain ethnic groups. However, the reality is less straightforward. Dayto-day experiences in many parts of the country indicate that members of different ethnic groups live together, relatively harmoniously, sharing many events in their daily lives despite the ethnic conflict, rival nationalisms, political manipulation and trauma that prevail as causal factors in the literature.

The following question is raised here: how can people of different ethno-religious backgrounds in such a volatile country develop common grounds to collaborate in their everyday social lives? To date, there are no empirical studies that provide an answer to this question. This paper discusses this question, approaching 'common grounds' as an existential reality constructed by people in different ways in their day-to-day lives. Among the many spheres in which the people of Sri Lanka collaborate, religion plays a major role (See Bastin, 2002; Obeyesekere, 1978; Obeyesekere, 1984; Obeyesekere, 1977; Gombrich and Obeyesekere, 1988; Goonasekera, 2007).

This paper describes how common grounds is reached by means of a religious practice often 
identified as "Pāda Yātrā" or 'a pilgrimage on foot' to the multi-religious site of Kataragama. In this article, the prime focus is on pilgrimage making, not on the rituals conducted at the religious site of Kataragama as discussed by many scholars, including the writers mentioned above. Pilgrimage making is part of the local history which is often hegemonised by both the dominant Sinhala nationalism of the South and the separatist Tamil nationalism of the north (Whitaker, 1990). This research is based on a rural village called Pānama in the eastern coast of Sri Lanka.

The Pānama village, an example of both Sinhalas and Tamils living in one social setting constructed as an amalgam of Sinhala and Tamil caste systems or Sinhalas and Tamil participation in pilgrimage to worship Hindu (i.e Tamil) god Murugan, is an example for the above argument. The everyday collaborations of members of multi-ethnic community is taken-for-granted and I will engage in a very brief overview in the following section on the construction of rigid ethnic boundaries out of complex identities, in order to set a background for the discussion on possibility of negotiating ethno-religious boundaries as explained in the Anthropological discourse on ethnic identity construction. The construction of ethnic groups through colonial and postcolonial project is "more or less elaborate and effortful attempts by groups to forget, deny, or obscure their resemblances" (Harrison, 2003: 345).

\section{THE INVENTION AND MAINTENANCE OF AN ETHNO-RELIGIOUS RIVALRY: A REFLECTION ON COLONIAL LEGACY IN POST-COLONIAL PRESENT}

My embodied subjective realities and the writings of scholars, including Daniel (1996), are witness to the difficulty of creating essentially combative ethnoreligious categories, e.g., Buddhist-Sinhala and HinduTamils, at risk of forgetting the complexities and fluidities of these groups. Some Buddhist-Sinhalas also practice Hinduism, Christianity and Islam or other forms of beliefs on the whole or bits and pieces of those religions in their everyday lives, as do some Tamils. It can be argued that the Sinhala/Tamil ethnic divide, with its stigmatised link to the Buddhist and Hindu religions, is a colonial invention supported by post-colonial maintenance and augmentation. Though the literature highlights about Hind-Tamil nationalism, I understand the practical involvement of Catholic priests is higher than the Hindu priests in constructing and maintaining Tamil nationalism. I also see the history of the rivalry, which is essentially a history of politics according to Spencer (1990) and Stokke (1998), as based on my own embodied subjectivity in a society that is often burdened with conflict, tension and war.

The recorded Sinhala history of the country suggests that for over 2500 years it has had a 'poly-ethnic' society. As explained in the historical records, two conflicting ethnic groups, Sinhalas and Tamils, arrived in the island from various parts of India during different periods. Muslims also have landed in Sri Lanka in different periods. Careful analysis of history prior to the $19^{\text {th }}$ century, the ideal resemblance of race, language, religion and political territory subsidised by nationalist discourse today, was not as particularly well elucidated as it is today by Nissan and Stirrat (1990), Tambiah (1986), Obeyesekere (2004) and Rajasingham-Senanayake (2004). Pre- and postcolonial history does not comply with the model of two conflicting nations imposed upon it by contemporary Tamil and Sinhala rhetoric (Nissan and Stirrat, 1990: 24). Tambiah (1986) identifies three types of differences, i.e., caste, geographical and communal aggregates that existed in Sri Lanka in the pre-colonial period. It was evident that the migrant communities from India had been absorbed into local Sri Lankan communities during the pre-colonial period as a means of maintaining social equilibrium. The island's native people had been living constituents of local or regional socio-political complexes - the kingdoms of Kotte, Kandy, and Jaffna - free from rivalry, unlike the "Sinhalas" or "Tamils" as they are increasingly imagined today.

At the time of the Portuguese arrival in Sri Lanka in 1505 , there were three kingdoms in the country; Jaffna, Kotte, and Kandy (Arasaratnam, 1998: 302-303). The Portuguese colonists initially united the kingdoms in the low-country to simply for administrative purposes. In time, the Dutch used almost similar tactics. Tambiah (1986) writes that during the Portuguese and Dutch colonisations, people increasingly became "enumerated and aggregated" according (a) to the Sinhala caste structure: Karāwa (fishermen), Salāgama (Cinnamon peelers); and, (b) Tamil castes: Mukkuvār (matrilineal Tamil caste), Vellāla, and Karaiyār. This caste distinction, which was evident in ancient chronicles such as the Mahavamsa was allegedly "biased towards [the] Sinhalas" (Horowitz, 1975: 117). Percival's writing on Ceylon's capital Columbo (today's Colombo) at the beginning of nineteenth century is a powerful testimony to the island's "mixture of nations, manners and religions", and "caste" and "class" groups, all of which had their unique "manners, customs and languages" (Percival, 1805: 136).

The island of Sri Lanka came under total British control after a treaty signed by the up-country elites 
allowing the British to arrest the last king of Sri Lanka, who was of Tamil descent. The betrayal of him resulted not due to his ethnicity, but due to other factors such as 'wicked' rule and clashes among elites (Gunawardana, 1990: 68-69). Up-country elites, who signed in Tamil, were among the aristocrat signatories to the treaty. It was also testimony to the rejection of primordial arguments pertaining to Sinhala-Tamil divisions. Later, the British administratively united the whole country and placed it under central administration as opposed to the regional kingdoms that existed when the Portuguese colonised the country.

The British administration's census-taking process sought to do away with the complexities and diversities such as caste, religion as well as the most marked regional variations and unique ruling mechanisms that existed within the same ethnic categories (See Tambiah, 1986; Rajasingham-Senanayake, 2004; Roberts, 1998). In general, the notion of pluralism resulted from colonisations by Western powers, and the formation of unitary institutional systems for the purpose of politics and government (Jenkins, 1986: 179). Tambiah (1986) and Rajasingham-Senanayake (2004) claim that the people of Sri Lanka lived as "components of local or regional socio-political complexes" rather than as the rival Sinhala/Tamil ethnic groups they are today. Tambiah (1986) argues that the Sri Lankan Tamil people, who are different from the Indian Tamil people, do not constitute a unitary group or a collective. They arrived in Sri Lanka from different parts of South India in different time periods and settled in the northern and eastern areas of the island. They have evinced internal differences in their customs, rituals, kinship patterns and inherent structure. The Tamils who lived in the eastern part of the country came under the political control of the Kandyan Kingdom rather than the Jaffna Kingdom. Furthermore, there were different communal aggregates; low country Sinhalas vs upcountry Sinhalas, and Jaffna Tamils vs the Batticaloa Tamils vs the Indian Plantation Tamils (Tambiah, 1986; Arasaratnam, 1998). The difference between the upcountry and low country Sinhalas was more significant than that between the Sinhalas and Tamils. This was very clearly shown in 1925 when upcountry Sinhalas sought regional autonomy for the Kandy region as a federal state, organising under a new association called the Kandyan National Assembly (Roberts, 1998: 454).

The British contributed to the growth of ethnonational consciousness by introducing laws on a broader spectrum, expanding from sexual union to land rights; Kandyan law for the upcountry Sinhalas based on territorial principles, and a special legal system
(Thesavalamai) for Tamils in Jaffna and Trincomalee covering their marriage and property rights (Nissan and Stirrat, 1990: 28; Wickramasinghe, 2006: 25). The inhabitants of the low lying areas were controlled by a separate Roman-Dutch law. The Muslims in an attempt to safeguard, sustain and advance their distinctive religio-cultural identity, joined forces with their colonial masters, gaining colonial state support for two distinctive areas, i.e., marriage and inheritance, and in the field of education (Zackariya and Shanmugaratnam, 1997: 22). These new codifications were reflective of European racial theory based on biological differences (Nissan and Stirrat, 1990: 28).

Nissan and Stirrat (1990) and others contend that the British colonisers connected already developed racial categories with politics, thus reifying a base for the contemporary ethno-political crisis (Zackariya and Shanmugaratnam, 1997; Rajasingham-Senanayake, 2004). Their establishment of a common administrative system for the whole of Sri Lanka in 1833 included a government by a governor, and legislative and executive councils. The British, seemingly conveniently, overlooked the extant political reality in the Kandyan kingdom wherein Sinhala and Tamil Nayakkara elites ruled the kingdom jointly. The tenets of Buddhism and Hinduism were respected and the British assumed power over the Kandyan kingdom peacefully in accordance with a treaty signed by both the Sinhala and Tamil elites. Three unofficial local members were nominated to the legislative council by the governor, representing the low country Sinhalas, the Burghers and the Tamils. In 1889, two more Kandyan (upcountry Sinhalas) and Moor members were added. The appointment of representatives for various ethno-racial groups was further practiced through changes made for the legislative council in 1910, 1920 and 1923, which resulted in increasing the number of representatives.

The post-colonial local political elites of all the ethnic groups in general, and of the Sinhalas and Sri Lankan Tamils in particular, competed to ensure their continued power and share of authority. In the process, political entrepreneurs drew upon cultural elements, that is, religion, language, ethnicity and other symbols, to strengthen the solidarity of the various groups and mobilise them as voters, ensuring their own continued power, wealth and prestige. In response, some Bhikkus entered the parliament via the Jāthika Hela Urumaya (JHU-National Heritage Party), heralding the day when Hindu, Catholic or Muslim clerics too would seek to enter parliament. The possibility of this happening, given the electoral competition among the political elites, cannot be ignored. This core aspect has been discussed 
by several scholars including Nissan and Stirrat (1990), and Rajasingham-Senanayake (2004), Spencer (1990) and Tambiah (1986). The country's political elites who have created these divisions in the interest of maintaining bank accounts for use in future elections, agitate against foreign states and international organisations such as the UNHRC or UNO that make allegations of human rights abuses.

In more recent times, ethno-religious nationalism has been created by combining the languages spoken and the elements of religions that are practiced, e.g., Sinhala-Buddhists and Tamil-Hindus. Previously, rivals engaged in a three-decade old war during which more than 100,000 people were killed (BBC, 2012); today the factions are facing allegations of war crimes. The political entrepreneurs are now struggling to use the war and its aftermath to perpetuate their political power centred in the state and to ensure the betterment of the ruling class and their kin over the next few generations. For the elites, State power is a way of life; it brings them all that they can wish for and they are exempted from punishment or accountability in line with changes made to the constitution or rule of law relevant to recent happenings in the country. The post-war Sri Lankan rulers intoxicated with power, argue about the constitution, the superiority of the executive, legislature and the judiciary, and better representation of the "people's mandate". In the process, they fail to address the issues critical to those war victims, who are struggling to rebuild their lives. They are intent upon "winning the hearts and minds" of the victims using an effective and broader post-war reconciliation mechanism via which they can "combine the hearts and minds" of the desperate ethnic groups. Amid all of this political confusion and manipulation, the ordinary people continue to pursue the mixed traditions that form the patterns of their everyday social lives. The Pāda Yātra or pilgrimage on foot is one example of everyday inter-ethnic collaboration that was observed in Pānama.

\section{A PHENOMENOLOGY OF PILGRIMAGE}

Barth (1994) advocates that anthropologists must pay attention to the experience through which an ethnic identity is formed in order to comprehend complex and subtle ethnic border negotiation. Here this is attempted by employing a phenomenological methodology; a study of experience and how one experiences, to study common ground building in ethnically volatile Sri Lanka, in the village of Pānama located in the eastern province of Sri Lanka. It is difficult to draw a clear distinction between its Buddhist-Sinhala and Hindu-Tamil residents as they unite in the Hindu religious practices of the Pulleyar Kovil (the Hindu temple) and Ampitiye devālaya (a local term for shrine). The first mentioned temple is dedicated to the god Pulleyar and the second to the goddess Pattini and her husband, prince Pālanga (in Sinhala) or Kōvalan (in Tamil). The Sinhala and Tamil people who are often projected as ethnic rivals, are combined in a social system based on caste structure, the Tamils and Sinhalas representing both high and low caste groups in one social system. The Goyigama (Sinhala) and the Vellāla (Tamil) are high caste groups, whereas the Padu (Sinhala) and Dhobi and Barber (Tamil) are low caste groups. The Sinhalas and Tamils who establish blood relationships via marriages among identical caste groups maintain their kinship ties for generations, despite the temporary lapses attributable to the war between the LTTE and the government military forces.

I undertook my field work in this beautiful village, where the inhabitants not only welcome visitors but tolerate them over time. I spent a year in 2011 and the beginning of 2012, simultaneously conducting fieldwork in Pānama and the neighbouring town of Pottuvil, in which Sinhalas, Tamils and Muslims live side by side as a community. Both villages were border zones during the war between the government armed forces and the LTTE. The latter rarely killed the Pānama villagers, other than on rare occasions in the Yāla forest, possibly due to blood relationships between Sinhala and Tamil. Sinhala Tamil unity appears not to be mechanical; rather, it seems a very natural cultural amalgam. Sinhalas and Tamils follow almost the same cultural system of beliefs, rituals, marriage patterns, language and a common culture. The Sinhalas who live in eastern province of the island can generally communicate in Tamil, the dominant language of the region which is spoken by both Muslims and Tamils alike. Fishing, cultivation, and horticulture were the villagers' main livelihoods. The village is home to approximately 400 Hindu-Tamil families, out of a total of 2000 families. Most of the Tamils are identified as dhobi, members of the washer caste.

The entire eastern province of the country is witness to a common religious and cultural belief pattern that transcends ethnic boundaries. Yalman (1967) and McGilvray (2011) claim that among these cultural patterns, marriage, caste and religious beliefs are commonly shared. Buddhists visiting Hindu temples and making various offerings are seen as part of the everyday lived reality of the people countrywide. Muslims are also taking part in these religious ceremonies, particularly in crisis situations (which was specifically witnessed at the Ampitiya devālaya in Pānama). 


\section{THE KATARAGAMA PĀDA YĀTRA: A PILGRIMAGE ON FOOT}

During fieldwork in Pānama, I took part in local religiocultural practices and attended Ampitiya devālaya and Pulleyar kovil for weekly rituals every Friday and on special festival days. I was able to participate in the main pilgrimage, The Pāda Yātra, which is a part of the broader Hindu religious culture of the eastern province of the island. This is the oldest and longest pilgrimage undertaken to worship the god Murugan, who is identified and referred to by many groups, including the local indigenous peoples, by different names; Kataragama deiyo or Kanda Surindu by the Sinhalas; Velan, Kandan, Kumaran, Murugan or Kartieya by the Hindu-Tamils; Itale Yaka (demon of the arrow) by the Vädda people; and Vanniya by the people from Vanni. Furthermore, this religious site is important for Muslims, who believe that this locus was home to Al-Khidr (also known as Hayat Nabi), 'the green man' (Davidson and Gitlitz, 2002). According to the myth, the god came to Sri Lanka from India and became friendly with the Vädda's (local indigenous people) daughter Valli, who were later called as Valli Amma. The god Murugan subsequently settled in a forest area of deep south in Sri Lanka, which is popularly called as Kataragama. Later, his Indian consort, Theyivanai Amma, joined him in Sri Lanka after all efforts to take back the god to India failed.

A religious site created for this god is located in a forest in the deep south of Sri Lanka, an area that is currently identified as Kataragama in Sinhala and Kathirkāmam in Tamil. A holy city developed around the shrine of the god Murugan, which is renowned among the Muslims of the world as Khidr-gama, the home of Al-Khidr (Gaffar, 2011). Kataragama, a multi-religious site, is not only the locus of god Murugan's and the shrines of his two consorts, Theivane Amma (his Indian consort) and Valli Amma (his Sri Lankan consort), but also Kiri Vehera (a Buddhist Temple), a Mosque and a shrine are located there. This religious site is located on the bank of the Manik Ganga (Manik River), where many of the people take a holy bath as part of purification process before they visit god Murugan. The main religious festival in honour of Murugan is held annually in the month of July for fifteen days at the devālaya premises. This festival which celebrates god Murugan's mythical extramarital love affair with the Vädda woman, Valli (McGilvray, 2010: 356), is known as Esala Uthsawaya (Esala Festival) in Sinhala, and Ādi Thiruvilā in Tamil.

During this festival, special ceremonies are held in Buddhist, Hindu and Muslim religious places located on the site. Kataragama is a melting pot; it attracts
Buddhists, Hindus, Catholics, Protestants and Muslims from all ethnic groups across the country- and from other countries- to participate in the pūja (offerings) (See Gombrich and Obeyesekere, 1988). According to Gombrich and Obeyesekere (1988), Hindu bhakti (religiosity) has successfully attracted Buddhists. Devotees visit Kataragama, and make vows and perform rituals of devotion in the hope that they will ultimately achieve success. Some devotees show their devotion by performing physical self harm, i.e., by piercing the bodies with pins, needles or pointed iron sticks (katu gaseema), by hanging from hooks (penetrating their skin), rolling in worship across the holy ground, fire-walking, and by performing the Kāvadi dance. In general, almost all the people who visit Kataragama offer pūja wattiya (offerings) to the god.

Among the thousands of pilgrimages that are made to this religious site, Pāda Yătra - or the pilgrimage on foot - is a special way of showing their devotion to the god. Pilgrims from the northern and eastern areas pass through Pānama: those who come from Jaffna in northern Sri Lanka walk approximately 450 kilometres for around 45 days. This pilgrimage starts in the wartorn north (Jaffna) and travels along the eastern coast, passing Muslim, Tamil, and Sinhala villages. The pilgrims come in groups of various sizes; they comprise males and females (young and adults) and some travel alone. Passing through Pānama, they then cross Yāla national forest before reaching Kataragama, which is located deep in southern Sri Lanka, where the Sinhala people are dominant. Approximately, between 20,000 30,000 pilgrims walk through Yāla forest per year; as most of the Sinhala and Tamil villagers of Pānama walk to Kataragama annually. The Wild Life Conservation Department keeps the gates of the Yâla national park open for approximately 10-15 days for the pilgrims.

The pilgrims stay in the kovils (Hindu temples), and in various halls along the way. The Okanda devālaya located in the Yâla forest is one of the places where they stay. It is a regional Hindu temple dedicated to the god Murugan. Simultaneous to the religious festival in Kataragama, the celebration of Okanda devālaya also starts. Pilgrims, mostly Hindu-Tamil people and Buddhist-Sinhalas, who do Pāda Yātra from various parts of the north and east, stay at least one night to get the blessings of the god Murugan. This means participating in the religious festival and starting to walk to Kataragama the following morning. According to myth, the Okanada devālaya is located where the god Murugan, who was travelling by canoe, landed and relaxed for some time on a strip of beach. He met Valli on this shore and became jubilant watching her dance. Legend has it that he made a rock 
from the overturned canoe (a thonigala or canoe shaped rock), and this is one of the sites that every pilgrim approaches very piously. The Pānama people claim that the temple was their responsibility before this area came under the control of the LTTE. However, currently, the administration of the temple is undertaken by the Hindu Tamils, who mostly live in Thirukkovil, another Tamil village in eastern Sri Lanka.

The festival of the Okanda shrine is held for fourteen days at its premises in Yāla forest. This annual festival may be seen as a fine illustration of inter-ethno-religious unity. Currently, there are three perahera (processions) among the 14 events allocated to the "Pānama people": one by Pānama villagers under the supervision of the head priest (Bhikkhu) of the Pānama Buddhist Temple; one by a Buddhist-Sinhala Goyigama villager; and, one by a high-caste Hindu-Tamil Vellāla resident. The day of the Pānama villagers' procession, Sinhala and Tamil villagers joined in the Perehera, carrying god Murugan's statue around the shrine. There were Sinhala and Tamil cultural items presented during the procession. The Muslim people of Pottuvil open their shops in the Okanda devālaya premises during the festival period. It is understood that the Muslims also make pūja (offerings) at this devālaya. They sell various fancy items including toys, plastic cups, bangles, rings and necklaces, plastic flowers, bags, slippers, and clothes, offer haircuts and shaves, and charge hand phones and camera batteries. Almost all of the goods sold on the temple grounds cost at least double the normal price of any item sold in Pānama or Pottuvil. Souvenir shop close to the devālaya sell statues of "laughing Buddha" (a Chinese folklore deity believed to be most auspicious god of wealth. Mahayāna Buddhists in East Asia believe he is a Maitree Lord Buddha who is yet to arrive), photos of Jesus Christ, St. Anthony, the goddess Saraswathie, Pattini, Murugan, and Vinayagar (names of the gods and goddess in the Hindu pantheon).

The distance from Pānama to Kataragama is approximately 105 kilometres. As stated above, the route goes through the Yâla national park. It take six days to walk to Kataragama from Pānama; but, experienced devotees may do the journey in three days, given they are truly in a hurry. The first day, our team decided to spend the night at Okanda shrine to participate in its annual ritual. On the second day, we stayed at Kuda Kebilitta and offered pūja. On the third day our tearm stayed at Lin Thuna (three wells), then two days at Menik Ganga (Gem River) and the sixth night was spent in Kataragama religious site. The waters of the Menik Ganga are considered holy, similar to the water of the Ganga (Ganges) in India.
The pilgrims take bags of essential items containing water, dry rations for cooking and making pūja at hundreds of small shrines dedicated to the god Murugan. In these shrines, devotees offer pongal (food prepared with rice, coconut milk, sugar and some grains) as part of pūja. People participate in the offerings and share pongal with others, a virtual indicative of the symbolical blessing of the god.

Irrespective of age and gender, any devotee who takes part in this holy walk is referred to as Sāmi. When one Sāmi passes another, he/she would bless "haro harā Sāmi..." to which the other pilgrim will reply "haro harā" (even if he/she very tired). Two BuddhistSinhala men who joined from Colombo with our team learned this form of blessing very quickly and continued to exchange greetings throughout the pilgrimage, receiving the appropriate response from their HinduTamil counterparts. The leader of our team, a 70-yearold Buddhist-Sinhala man from Pānama, used to sing devotional songs praising god Murugan that proved attractive to other pilgrims. Some experienced Sāmis often gave advice to new Sāmi (like me, who participate for the first time) regarding reducing the difficulty of prolonged walking.

Although we noted food stalls run by Army officers in the forest, they did not have enough of the goods that the people wanted. The Buddhist-Sinhala members of the our team who had travelled the route many times before, recalled how they did the Pāda Yātra when a part of the Yāla national park was controlled by the LTTE, whereas the other part was controlled by the government forces. One lady in our team recalled how well the LTTE had treated them. She became angry when she saw military personnel shirking their duty and yelled at them, telling them that they were always given sufficient facilities, even during the war.

The Sāmis had to walk under the burning sun and cross lagoons, streams and meadows with bags of the most essential items on their heads. The very dry weather and seasonal gusty winds rendered the pilgrimage very difficult. One risked attacks by wild elephants and other animals. A Hindu-Tamil teacher was attacked by wild bears when she went to answer a call of nature one morning. During the pilgrimage people talked to each other freely; they created new friendships, some even ending in marriage. Few members of our tearm (including me) suffered from blisters (diyapatta). There was an army doctor and a nurse at Warahana, close to Kataragama, who provided some medicine for us. On the sixth day, we reached Kataragama after passing 
through the villages of Kochchipatana, Katagamuwa and Tissa. The team bathed in the Menik Ganaga before offering pūja to god Murugan. It was noted that dansala (free food places) had been organised by various charity organisations. Our team and other Hindu and Sinhala pilgrims were provided with lunch and dinner from those places. It was observed that many of the Sinhalas and Tamils visiting the Mosque were adherent to Sufism and asked the fakir (Muslim cleric), about their future. Muslim school children walked to Murugan temple and Buddhist temple as well. There are Buddhist-Sinhalas, Hindu-Tamils, Muslims and Christians attending Kataragama devālaya during this festival period. They joined together to watch perehera in the evenings and participate in religious activities held at the Mosque.

\section{THE GENERATIONS OLD PROCESS OF RELATIONSHIP BUILDING}

The Pāda Yātra, a multi-religious practice that has been handed down from generation to generation, is becoming increasingly marginalised and trivialised, considered a subaltern phenomenon in scholarly discussion held amidst Sri Lanka's ethno-political war. The literary records of this pilgrimage were discovered in 1870s and attracted considerable attention in the early nineteenth century (Davidson and Gitlitz, 2002: 309; Gombrich and Obeyesekere, 1988: 182). My own multilingual (Sinhala-Tamil) capacity and experience of living with Tamil neighbours, and the long stay in Pānama equipped me to understand this ethno-religious practice more fully than some other researchers were able to.

Victor Turner's writings on liminality and communitas have proven very useful to explain the process of relationship building among the Sinhalas and Tamils. Turner borrowed the concepts from Arnold Van Gennep's usage of "liminal phase" of rites de passage. Van Gennep defined rites de passage as "rites, which accompany every change of place, state, social position and age" (in Turner, 1969: 94). Turner uses the term 'state', where changing position of the actor is well represented. According to Van Gennep, rites of passage have three stages; separation, marginal and aggression. In the first stage, the actors detach from their previous fixed social points in the social structure or cultural condition (state), or both. In the second, the liminal phase, the actor is in a state of ambiguousness; "he passes through a cultural realm that has few or none of the attributes of the past or coming state" (Turner, 1969: 94). In the last stage; the actor is in a more stable relationship. Turner explicates the importance of liminal phenomena in his discussion of communitas;

"What is interesting about liminal phenomena for our present purposes is the blend they offer of lowliness and sacredness, of homogeneity and comradeship. We are presented, in such rites, with a 'moment in and out of time', and in and out of secular social structure, which reveals, however fleetingly, some recognition (in symbol if not always in language) of a generalized social bond that has ceased to be and has simultaneously yet to be fragmented into a multiplicity of structural ties. These are the ties organized in terms either of caste, class, or rank hierarchies or of segmentary oppositions in the stateless societies beloved of political anthropologists" (Turner, 1969: 86).

My discussion on liminality is an evolving concept as I reflect on Victor Turner's research. Victor Turner's notion of liminality discussed in relation to ritual process is important as there is a very little concern on that here within social science scholarly discussions in Sri Lanka. The liminal individuals (those people who are in a liminal condition) are

"neither here nor there; they are betwixt and between the positions assigned and arrayed by law, custom, convention, and ceremony" (Turner 1969: 95).

In this stage they are not in the known structure or unknown structure but in-between which creates a lot of ambiguities, risks and unpredictability. Perhaps my addition to the discussion of liminality by Turner is different stages of liminalities. The pilgrims enter into a liminal stage in general from the moment they leave home for Kataragama and also they enter into the liminal phase from the moment they decide to engage in this pilgrimage. From the point they decide to engage in this ritual they start observing certain practices which follow the qualities of broader "humanity". Furthermore, they all enter into a very high scale of ambiguities as they set foot in Yāla national forest reserve as there is no known structures to help them in a time of a crisis.

The pilgrims experience high level of ambiguities (higher level of liminal phase) as they pass through Pānama (known structures) into "Kataragama Deiyange Adaviya" (god Murugan's region) where the god's notions of "good" and "bad" or "justice" and "injustice" prevail as the main administrative rule. Up to that point, they have been passing through known areas, recognising known symbols, and enjoying life. They have been moving from one temple / camp site to another, enjoying the hospitality of the villagers (McGilvray, 2010: 356). The people of Pānama also provide dansala for the pilgrims. After leaving Okanda devālaya, the travellers have to deal with extreme conditions and look for help from the god Murugan. After sleeping on a cement floor 
overnight (which I considered my best sleep in front of god's chambers), I prepared for the rough conditions ahead. From the outset, the pilgrims understood the rough nature of the pilgrimage. When they gradually understood the difficulties involved, they started to voluntarily help each other.

The pilgrims are very concerned with their purity and try not to commit any wrong doing or "killa" (plural "kili", meaning 'pollution') which will make the god angry. They do not eat meat, fish or eggs: they only eat vegetables. In addition, they cease drinking alcohol before the trip and abstain during the walk. They avoid harming, lying to or insulting others, actions considered "kili". When a man from one of the Pānama teams was bitten by a serpent, some members of that group and the research team assumed that it was his punishment for taking part in the pilgrimage while one of his daughters was celebrating puberty ceremony ("loku lamayek wela"). This example shows the extensive concerns surrounding "killa". The devotees commit to ceasing wrong doing a few weeks prior to the pilgrimage. They use the term "kata waradda ganna epa" (don't mince your words) meaning avoid conflicting relationships. People are required to think about 'good things'. They know that if they expose their anger to the god they will be punished and their expectations will not be fulfilled. They are governed by the god's rule which is different from the everyday administration by a set of corrupt officials who can often be bribed. This concept echoes Bastin's (2002) "create cosmic possibility", i.e., the articulation of difference in South Asian society and history. Each and every person acts in the hope that his/her expectations will be fulfilled. For example, eliminating financial problems, building a house, getting a job, hoping for better health, for promotion, expectations that will never be shared, are nonetheless significant. One woman in our group was on her $10^{\text {th }}$ visit. She had made a vow to the god Murugan and in return expected his support for relief for her son who suffered from asthma and was very dedicated. Thus, being pleasant to others, and not becoming "kili", is rewarded.

The pilgrims are handling "uncertainty", "unpredictability" of the liminal stage by adhering to broader values such as humanity and brotherhood. This is the space which accommodate creating bonds and solidarities across the ethno-religious boundaries. In a risky and uncertain situation helping a fellow human being, while it can be inconvenient as all suffer in the same manner, is the only way out of the uncertainties and risks through which god can be pleased and his support to achieve their vows can be obtained. They aspire to live the way their god wants them to live. A further incentive is that they fear punishment by the god Murugan if they do not behave (exposing to "kili") in the way the god expects. During the long pilgrimages people undertake, they tend to make friendships, which encourages them to participate again. In general, it is difficult to find someone who has made the pilgrimage only once. I met many who had participated at least ten times. Pilgrimages liberate participants from their often mundane day-today statuses and roles.

Identifying a pilgrim as Sāmi, irrespective of age, gender, caste, ethnicity, religion or indeed any sociopolitical division, neutralises the often pompous ego or self that disturbs the humanness in the everyday lives of those who live in conflict ridden societies. Once in the forest, there are no politicians to divide people, to goad them into fighting as has been the case throughout the post-independence political history of Sri Lanka. Among the devotees, I found people from varying occupations: doctors, teachers, education directors, local politicians, and businessmen. Furthermore, the members were of different ages and sexes. Some parents took very small babies and toddlers on the pilgrimage as a way of fulfilling the vows they had made to the god Murugan. Irrespective of whether one is of an ethnic majority or an ethnic minority, they are all vulnerable to physical weakness when undertaking pilgrimage. The hardship they experience is one of life realities, i.e., common "human" suffering. Sometimes they miss their old groups and join new groups. Some ladies and children walk unescorted. The pilgrims who take part in this pilgrimage leave the usual worldly goods behind. The Sāmis who took part in this pilgrimage left everything behind other than a parcel of essentials, i.e., foodstuffs, cooking utensils, biscuits, noodles, water, medicines, instant food and clothes, which they carried on their heads.

In this way, not only did they experience a life of a homeless person, beggar or hermit, but, learn deep profound lessons about the reality of life through acts of self-denial. Sāmis sleep and live outside, often under the shade of a tree. They do not know when or if their next meal will eventuate. They fear wild animal attacks, suffer from blistered feet, have to dig in the sand in search of water, to cross muddy lagoons, streams and rivers, fear thunder storms and often have to travel under the hot sun and in dusty conditions that slow their movements. Clearly, devotees who go on this pilgrimage fully commit themselves, as evident in the simplicity of their lives.

Sāmis are never reluctant to ask for help or to offer help. When we crossed the Kumbukkan Oya (the river Kumbukkan) the Hindu-Tamil boys extended their hands to help us to climb onto the slippery riverbank. They 
were concerned about the safety of the other Sāmis even though they did not know them personally. Two boys came to the place in which we stayed in Menik Ganga and asked for curry. In return, they gave us chillies that were very useful because our chilli supply was exhausted. In a place called Lin Thuna (three wells), groups of Sinhala and Tamil people together went in search of water so that they could bathe. Members of our team and other groups made a lengthy walk to a spring to fetch water, even after dark. The devotees borrowed buckets, cups, mats, lights and water from each other when in need.

The risks involved in the pilgrimage inspired unity across ethno-religious borders that is often politicised in their everyday lived reality in the villages. The devotees continuously pray to god Murugan for protection from disastrous rains, wind, attacks by wild animals, diseases and physical difficulties. There is a great belief that the god Murugan will protect those who follow his guidance. Therefore, Sāmis always invoke blessing by saying "haro..harā....", as well as offering pūja along the way. In the evenings some Tamil ladies sing Bagawath Geetha and bakthi (devotional) songs. I joined with them at some points. When they feel threatened by wild elephants or heavy rain, all invoke the blessing and attention of the god Murugan by shouting " haro..harā...". After a while, the threats disappear.

During the pilgrimage, I met Sinhala and Tamil people travelling in mixed groups, some from Pānama and Pottuvil, who were related through marriage. They were able to converse in both Sinhala and Tamil. I talked to a young man from Pottuvil, who was a representative of these ethnically-mixed groups of devotees. I conversed with him for the first three days in Tamil until I came to know his name. It was only when I asked for his contact details that I came to know that the youth was a Buddhist-Sinhala, whose father managed an eatery in Pottuvil town. Some of the Tamil men in the groups of pilgrims from Pānama had married Sinhala ladies of the same high-castes; thus they had maintained caste consciousness across ethnic borders: Sinhala Goyigama caste marrying Tamil Vellāla caste.

However, I prefer to indicate a widely believed mythology in summary form which highlight the different treatment of god Murugan for devotees from Sinhala and Tamil ethnic groups. According to the story, when Murugan visited Kataragama he appeared as an old man. He asked a group of Tamils if they would make a hut for him to settle in because it was going to rain. The Tamils disregarded his request. Then Murugan saw a group of Sinhala boys and made the same request of them. The Sinhala boys who were very kind, made the hut for the old man. A group of Muslims also helped him.
Then, Murugan said: "The Sinhalas and Muslims came to my wedding (to Valli Amma) but you Tamils did not help me. Therefore, you should all come to meet me by walking across difficult terrain every year". However, the position that the god assumed did not create distinctions or divisions among the island's ethnic groups. The Sinhalas, who mainly live in the east coast, take this difficult route along with their Tamil counterparts, in shared spirit of belief and devotion. During the journey, I also noticed the occasions where ethnic references were made but they were nothing but casual remarks only.

As McGilvray (2010: 357) suggests, following the end of the war in 2009, the Tamils no longer had military questioning at every checkpoint. However, there was one military checkpoint in Warahana where all of our bags were unpacked and thoroughly checked. Warahana is the entry point at Tissamaharamaya, a neighbouring town in southern Sri Lanka. The military personnel explained that they were averting the possibility of hidden weapons being transported secretly to Tissamaharamaya from where they could be transported to terrorist targets in Colombo and other places. However, the pilgrims were not particularly worried by the checking. They undertook the pilgrimage even when the LTTE and army maintained similar checkpoints in the Yâla national park. Neither the army nor the LTTE disturbed the devotees, meetings with the god Murugan as they feared being cursed by the god.

During the pilgrimage, the Pānama people in the team met relatives from Tamil areas including Thirukkovil, Mandavil, Akkaraipattu and Batticaloa. The team leader often talked to his Tamil relatives and was clearly very happy to meet them after such a long time. They exchanged information about others they knew, and shared food and drinks. No one was conscious of ethnicity; they shared a bottle of soft drink, used the same cups or simply drank from the bottle. In the aftermath of the war, the military and security no longer strictly blocked meetings between Sinhala and Tamil relatives, something I personally experienced when attending the wedding of a Pānama man to Tamil girl from Thirukkovil (which was also attended by their Sinhala-Tamil relatives).

Communitas has its benefits. There are some cases of Sinhala and Tamil mixed-marriages, evidenced in village poems, unions that foster long-term friendships. I conducted some interviews with elderly people who had found their partners during the pilgrimage. I still remember people from Batticaloa with whom I developed a very sound friendship. Pānama locals, some of whom later became writers, e.g., Gunasekara Gunasoma and Kiribanda (the villagers identify him as Peon Seeya or Peon Māmā which can be translated into English as "Peon grandpa" or "Peon uncle"). According 
to Peon grandpa, earlier the Tamil pilgrims used to stay in Pānama Buddhist temple, school and Kittange (an old hall used to store paddy harvest of the villagers) before proceeding to Yāla forest. This supports Hermkens et al.'s (2009) notion that

"the interaction with other pilgrims may result in a strong sense of communitas, which engenders shared spiritual emotions and possibly a shared sense of the presence of the divine among them" (Hermkens et al., 2009: 9).

The pilgrims exchange addresses and telephone numbers, then returned to their villages with good memories of the Sinhala people of Pānama which they share with others. They look forward to rekindling their friendships next pilgrimage. When the research team arrived in Pānama, they understood why the villagers accepted them so readily, as people who had participated in Pāda Yātra. Buddhist-Sinhala friends, who participated in Pāda Yātra, returned home pondering how best they could make the following year's trip.

Pāda Yātra is not a journey that devotees engage in once in a lifetime. It is an act of repetition, a practice of pilgrimage similar to Bourdieu's theory of practice (McCorriston, 2011; Coleman and Eade, 2012). People on the east coast of the country have an almost compulsive urge to take part in the pilgrimage. This internal compulsion seems to result from embodied religious practices handed down through generations. I often met people who had undertaken pilgrimage in excess of ten times for various reasons. Their commitment ensures the continuation of all of the above practices: emphasis on humanness and existentional needs, concepts well explained through Bourdieu's concept of habitus; i.e., "systems of durable, transposable dispositions, structured structures predisposed to functions as structuring structures" (McCorriston, 2011: 55; Coleman and Eade, 2012: 37). According to McCorriston (2011), "practices are both generated by and reproduce the framework of tendencies that shape decisions about what people do". Pilgrimage includes rationality of action habitual to those who participate in it: pilgrims reproduce a "defining framework of culture", trusting in "bodily habituation rather than [in] cognition" (McCorriston, 2011: 55). I observed this phenomenon in the narratives of pilgrims who repeatedly participated in the Kataragama Pāda Yātrā.

\section{CONCLUSION}

Though ethno-religious divisions appear as primordial objects, they are colonial inventions and post-colonial maintenance. These divisions led for the three-decade old war which militarily ended in 2009. However, the post-war Sri Lankan governments do not seem to be paying adequate attention to combining the "hearts and minds" of the conflicting ethnic groups and they prefer to be resorting to power sharing and federal solution mantra, mainly dominated by the political scientists. In this context, ordinary people with multi-ethno-religious backgrounds continue their inherited practices and relationships in their everyday social life worlds which is also their existential realities. Otherwise, their everyday lived reality will become burdened with socio-economic and political travail. This paper attempted to show how the Buddhist-Sinhalas and the Hindu-Tamils who live in the eastern Sri Lanka (which was once a war torn area) continue their common religious practices in post-war Sri Lanka just as they have done for many past decades, including the war period. It emphasised the fact that the "liminal" condition created during the pilgrimage contributes to create collaboration even among the unknown pilgrims from rivalry ethno-religious groups, using the theories of Victor Turner (1969) and Hermkens et al. (2009). Pilgrimage-making has become an embodied habitual practice explained by Bourdieu (McCorriston, 2011) and this embodied practices push multi-ethno-religious communities to expose to liminal conditions annually. The liminality involves ambiguities, risks and uncertainties which necessitates connections among the participants on the basis of broader human values. This situation contributes towards creating essential inter-dependence and establishing and maintaining relationships among the Sinhala, Tamil and Muslim communities in the areas. This pilgrimage making is one of the 'subaltern' practices of ordinary people who are, in the main, disregarded in the ethnopolitical debate dominated by the political elites of their own ethno-religious groups.

\section{REFERENCES}

Arasaratnam, S. (1998) Nationalism in Sri Lanka and the Tamils, In Roberts, M. (eds.) Sri Lanka: Collective identities revisited. Colombo: Marga Institute.

Barth, F. (1994) Enduring and emerging issues in the analysis of ethnicity, In Vermeulen $\mathrm{H}$. and Govers, C. (eds.) The Anthropology of Ethnicity: Beyond 'Ethnic Groups and Boundaries, Amsterdam: Het Spinhuis.

Bastin, R. (2002) The domain of constant excess: plural worship in a Sri Lankan Hindu temple, New York: Berghahn Books.

BBC NEWS (2012) UN 'failed Sri Lanka civilians', says internal probe [Online] Available from: http://www.bbc.com/ news/world-asia-20308610 [Accessed: $8^{\text {th }}$ June 2017]. 
Coleman, S. and Eade, J. (2012) Reframing pilgrimage: cultures in motion, London: Routledge.

Daniel, E.V. (1996) Charred lullabies: chapters in an anthropography of violence, Princeton NJ: Princeton University Press.

DOI: https://doi.org/10.1515/9781400822034

Davidson, L. K. and Gitlitz, D. M. (2002) Pilgrimage: from the Ganges to Graceland : an encyclopedia, Santa Barbara: AbcClio, Inc.

Gaffar, M. H. A. (2011) Kataragama mosque and shrine, Kataragama: Author's publication.

Gombrich, R. and Obeyesekere, G. (1988) Buddhism transformed: religious change in Sri Lanka, Princeton: Princeton University Press.

Goonasekera, S. (2007) Walking to Kataragama, Colombo: International Centre for Ethnic Studies.

Gunawardana, R. A. L. H. (1990) The people of lion: the Sinhala identity and ideology in history and historiography, In Spencer, J. (eds.) Sri Lanka: history and the roots of conflict, London: Routledge.

Harrison, S. (2003) Cultural difference as denied resemblance: reconsidering nationalism and ethnicity, Comparative studies in society and history, [Online] 45 (2), pp: 343-361, Available from: http://www.jstor.org/stable/3879319 [Accessed: $31^{\text {st }}$ September 2011].

Hermkens, A. K., Jansen, W. and Notermans, C. (eds) (2009) Moved by Mary: the power of pilgrimage in the modern world, Burlington: VT Ashgate.

Horowitz, D. L. (1975) Ethnic identity, In Glazer, N. Moynihan, D. P. and Schelling, C. S. (eds.) Ethnicity: theory and experience. Cambridge, Mass: Harvard University Press.

Jenkins, R. (1986) Social-Anthropological models of interethnic relations. In Rex, J.M. (eds.). Theories of race and ethnic relations. Cambridge: Cambridge University Press.

DOI: https://doi.org/10.1017/CBO9780511557828.010

McCorriston, J. (2011) Pilgrimage and household in the ancient near East, Cambridge: Cambridge University Press.

McGilvray, D. B. (2010) Pilgrimage to Kataragama, Sri Lanka, Visual Anthropology, 23, pp: 356-357.

DOI: https://doi.org/10.1080/08949468.2010.485019

McGilvray, D. B. (2011) Crucible of conflict: Tamil and Muslim society of the east coast of Sri Lanka, Colombo: Social Scientist's Association.
Nissan, E. and Stirrat, R. L. (1990) The generation of communal identities, In Spencer, J. (eds.) Sri Lanka: history and the roots of conflict, London: Routledge.

Obeyesekere, G. (1977) Social change and the deities: rise of the Kataragama cult in modern Sri Lanka, Man, [Online] New Series, 12, (3/4), pp: 377-396, Available from: http:// www.jstor.org/stable/2800544?seq=1\#page_scan_tab_contents [Accessed: 24 ${ }^{\text {th }}$ April 2012].

Obeyesekere, G. (1978) The fire-walkers of Kataragama: the rise of bhakti religiosity in Buddhist Sri Lanka, The Journal of Asian Studies [Online] The Association for Asian Studies Database, Available from: http://www.jstor.org/stable/2053572 [Accessed: $4^{\text {th }}$ July 2012].

Obeyesekere, G. (1984) The cult of the goddess Pattini, Chicago: University of Chicago Press.

Obeyesekere, G. (2004) Buddhism, nationhood, and cultural identity: the premodern and pre-colonial formations, Colombo: International Centre for Ethnic Studies.

Percival, R. (1805) An account of the island of Ceylon: containing its history, geography, natural history, with the manners and customs of its various inhabitants, London: C. and R. Baldwin.

Rajasingham-Senanayake, D. (2004) Identity on the borderline: modernity, new ethnicities and the unmaking of multiculturalism in Sri Lanka, In Silva, N. (eds.) The hybrid Island: culture crossings and the invention of identity in Sri Lanka, Colombo: Social Scientists' Association.

Roberts, M. (1998) Problems of collective identity in a multiethnic society: sectional nationalism vs Ceylonese nationalism, In Roberts, M. (eds.) Sri Lanka: Collective identities revisited, Colombo: Marga Institute.

Spencer, J. (1990) Introduction: the power of the past, In Spencer, J. (eds.) Sri Lanka: history and the roots of conflict, London: Routledge.

DOI: https://doi.org/10.4324/9780203407417_chapter_1

Stokke, K. (1998) Sinhalese and Tamil nationalism as postcolonial political projects from 'above', 1948-1983, Political Geography. 17 (1), pp: 83-113.

DOI: https://doi.org/10.1016/S0962-6298(96)00070-4

Tambiah, S. J. (1986) Sri Lanka: ethnic fratricide and the dismantling of democracy, London: I.B. Tauris \& Co. Ltd.

Turner V. (1969) The ritual process: structure and antistructure, New York: Cornell University Press. 
Whitaker, M. P. (1990) A compound of many histories: the many pasts of an east coast Tamil community, In Spencer, J. (eds.) Sri Lanka: history and the roots of conflict, London: Routledge.

Wickramasinghe, N. (2006) Sri Lanka in the modern age: a history of contested identities, Honolulu: University of Hawaii Press.
Yalman, N. (1967) Under the Bo tree: studies in caste, kinship, and marriage in the interior of Ceylon, Berkeley: University of California Press.

Zackariya, F. and Shanmugaratnam, N. (1997) Communalisation of Muslims in Sri Lanka: a historical perspective, In Munnani M. M. Ā. C. (eds.) Alternative Perspectives: A Collection of Essays on Contemporary Muslim Society, Colombo: Muslim Women's Research and Action Forum. 